\title{
Performance of Nutri Pellet Pack Technology in Sugarcane Yield and Uptake under Drip Irrigation
}

\author{
TH.SA. Raja Rajeshwaran ${ }^{1 *}$ and K. Arulmozhiselvan ${ }^{2}$ \\ ${ }^{1}$ Department of Soil Science and Agricultural Chemistry, Tamil Nadu \\ Agricultural University, Coimbatore, India \\ ${ }^{2}$ Department of Soil Science and Agricultural Chemistry, Anbil Dharmailangam Agricultural \\ College and Research Institute, Trichy, Tamil Nadu Agricultural University, India
}

*Corresponding author

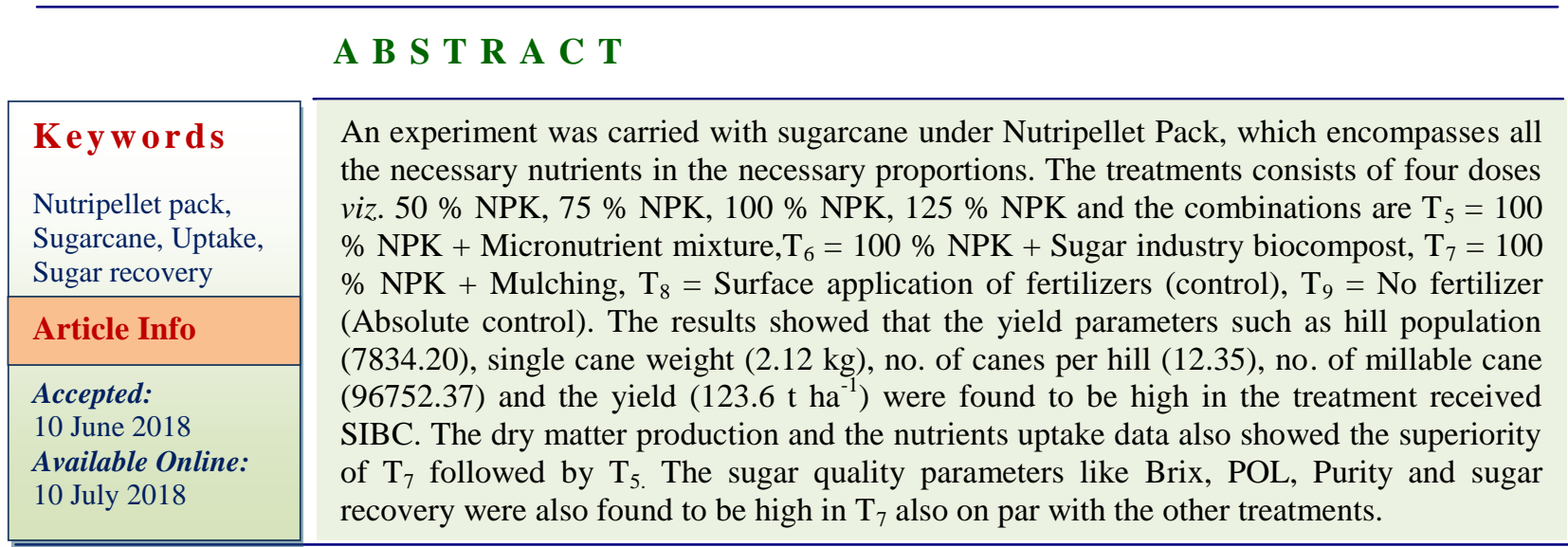

\section{Introduction}

Sugarcane is an important commercial agricultural cash crop, grown on 4.5 per cent of the total cropped area of the country. India ranks $5^{\text {th }}$ position (2016) in sugarcane area and $12^{\text {th }}$ position in recovery of sugar from the cane. However, the cultivation of sugarcane is known for heavy consumption of synthetic fertilizers, irrigation water, micronutrients and organic sources. Farmers use imbalanced inorganic fertilizers and pesticides injudiciously expecting to harvest good yield. In spite of that, the continuous use of chemical fertilizers in the soil disturbs soil health and quality which do not support plant growth in long term basis.

At present, around 3.51 lakhs ha area is under drip irrigation in India and 55,000 ha in Tamil Nadu. As the efficiency of surface irrigation is about $30 \%$ to $40 \%$ and sugarcane being a high water requiring crop the drip irrigation is found to be more suitable for a long duration crop like sugarcane with an irrigation efficiency of $80 \%$ to $90 \%$ (ICAR, 2017). Despite India's large area under sugarcane cultivation, sugarcane yields have been 
unimpressive and during the last 10 years, sugarcane production has been fluctuating between 233 and 355 million tonnes (Pandian et al., 2014). The productivity of the cane in Tamil Nadu declined from $103.37 \mathrm{t} \mathrm{ha}^{-1}$ (2011-2012) to $92.12 \mathrm{t} \mathrm{ha}^{-1}$ (2012-2013). The wide variation in soil fertility is a major limitation in reaching higher yield goals which can be improved by balancing N, P, K and micronutrients (Singh et al., 2008).

Generally, 75 per cent of chemical fertilizers are applied as surface broadcast. Nowadays instead of surface broadcast of fertilizers under surface irrigation, using water soluble fertilizers under drip irrigation is gaining importance. These surface application methods of fertilization are not nutrient efficient. Efficiency of fertilizers can be much improved by deep placement methods like Nutripellet Pack technology in which encapsulated fertilizer pellet is placed in the crop root zone. In this situation of surface application methods, much simplified root zone placement of Nutripellet Pack will be much preferable since it is one / two time placement.

In the present investigation it was aimed to develop Nutripellet Pack having slow release nutrient characteristics to support Sugarcane crop up to 10 months or more. The effect of prolonging nutrient availability in the root zone during growth and yielding stages of sugarcane was studied to harvest the possible yield improvement by comparing to the existing methods of fertilization without reduction in sugar quality and recovery.

Among the various abiotic factors, water deficiency must be highlighted due to the harmful effects caused on plant development, primarily through the reduction of cell expansion. The problems caused by the decrease in soil water availability are common in sugarcane fields, since they are not limited to only arid and semiarid regions in the world.
In regions considered as climatically humid, irregular rainfall distribution can, in some periods, limit plant growth (Silva et al., 2014).

Although this crop is adapted to conditions of high luminosity intensity, high temperatures and relative water scarcity, water deficiency during the stages of growth and development can lead to expressive reductions in stalk and sugar yield (Dantas et al., 2006). Thus, sugarcane producers depend greatly on irrigation to achieve production goals. However, this technique only has no applicability and needs to be combined with other agricultural management practices (Dalri et al., 2008), such as nitrogen fertilization, which is one of the main determinant abiotic factors for sugarcane production, especially with respect to the longevity of the ratoons (Muchow et al., 1996). Therefore, inadequate management of nitrogen fertilization in sugarcane fields may lead to reduction in crop yield and longevity, thus decreasing the number of harvests or cuts between the renovations (Vale et al., 2013).

\section{Materials and Methods}

The Nutripellet Pack (NPP) has 2 parts viz., Top: manure pellet and bottom Fertilizer pellet. The manure pellet is made of vermicompost. In fertilizer pellet was prepared with calculated amount of NPK fertilizers which was encapsulated in polymer paper (bio degradable).

The study was carried out to envisage the outcome of Nutripellet placement method on the yield of cane, and quality of sugar. Further it was also to evaluate the effectiveness of deep placement of fertilizer nutrients in comparison with surface broadcast of fertilizers, under different NPP treatments in a field experiment under drip irrigation. For the whole crop period it was aimed to grow sugarcane crop with the nutrient support of NPP placement, two times. 
Nutriseed Pack is a small tubular assembly (20 $\mathrm{mm}$ diameter, $10 \mathrm{~cm}$ height), which contains manure pellet in the top and fertilizer pellet at bottom. Calculated quantity of $100 \%$ recommended dose of NPK fertilizers for sugarcane crop was mixed up thoroughly and fertilizer pellet was prepared by using the fertilizer pellet making machine. Then each fertilizer pellet was sealed inside a polyester coated paper pouch having micropores and sealed by heat sealing machine. The polymer coated paper used was prepared by coating a normal paper with thin polyethylene sheet having short and broken polymers which helps in nutrient release and also leads to faster disintegration of the polymer material in soil.

It is expected that through the spaces, nutrients slowly dissolve out and then diffuse in soil water or move through capillary water. Thus, the slow release phenomenon is achieved by the polymer encapsulation and stands for the positive performance of fertilizer component in NPP. Soon after planting chip bud settlings, Nutripellet Packs were placed in soil at $5 \mathrm{~cm}$ depth and $5 \mathrm{~cm}$ horizontal distance from the chip bud. Then in these plots 9 treatments were imposed and replicated thrice in Randomized Block Design.

\begin{tabular}{|c|c|c|}
\hline T. No. & Treatments & Details \\
\hline $\mathrm{T}_{1}$ & NPP: $50 \%$ NPK & -- \\
\hline $\mathrm{T}_{2}$ & NPP: $75 \%$ NPK & -- \\
\hline $\mathrm{T}_{3}$ & NPP: $100 \%$ NPK & $\begin{array}{l}100 \text { per cent }= \\
300: 100: 200 \mathrm{~kg} \\
\mathrm{~N}, \mathrm{P}_{2} \mathrm{O}_{5} \text { and } \mathrm{K}_{2} \mathrm{O} \\
\mathrm{ha}^{-1}\end{array}$ \\
\hline
\end{tabular}

$\mathrm{T}_{4} \quad \mathrm{NPP}: 125 \% \mathrm{NPK} \quad--$

$\mathrm{T}_{5} \quad \mathrm{NPP}: 100 \% \mathrm{NPK}$ MN: $+\mathrm{MN} \quad$ Micronutrient mixture at $50 \mathrm{~kg}$ $\mathrm{ha}^{-1}$

$\mathrm{T}_{6} \quad$ NPP: $100 \%$ NPK Mulch:

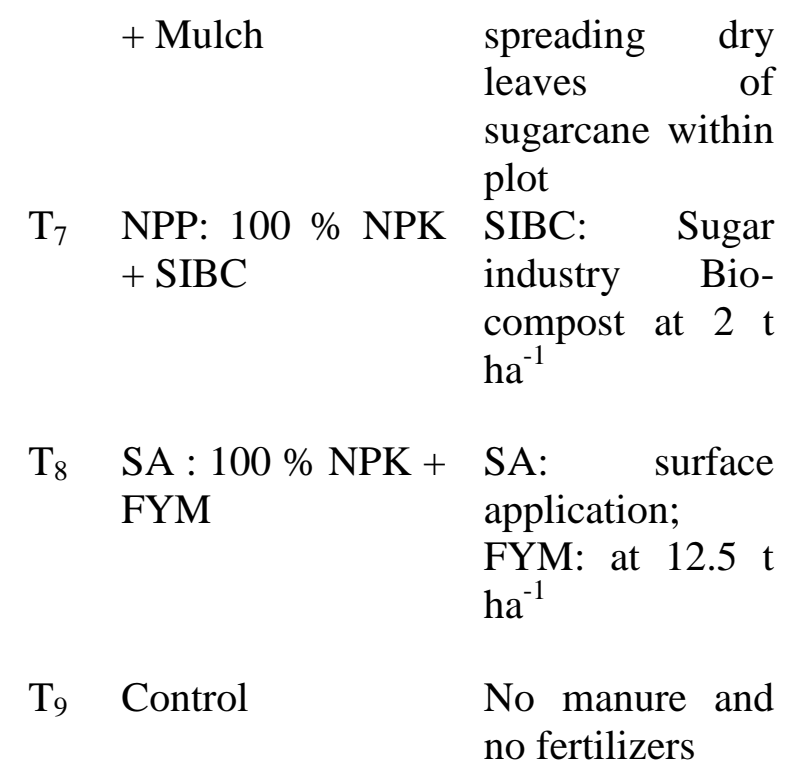

\section{NPP- Nutripellet pack}

The sugarcane variety CO 86032, a ruling variety for last 15 years in Tamil Nadu, was used for the field experiment. Protray with 23 days old sprouted chip bud settlings was used. The $100 \%$ recommended dose of fertilizer at 300:100:200 kg N, $\mathrm{P}_{2} \mathrm{O}_{5}$ and $\mathrm{K}_{2} \mathrm{O} \mathrm{ha}^{-1}$ as blanket recommendation was adopted. Urea, diammonium phosphate and muriate of potash were used as source of fertilizers. As per treatment, NPP were placed in two splits. First split as basal and the second split at 90 days during earthing up.

The field experiment was conducted at the Research and development farm of Bannari Amman Sugars Ltd, Alathukombai, Sathyamangalam taluk, Erode district, Tamil Nadu, India.

For surface application $\left(\mathrm{T}_{7}\right) 100 \% \mathrm{P}$ and $50 \%$ $\mathrm{K}$ and $50 \% \mathrm{~N}$ was applied at basal. The remaining $50 \%$ of $\mathrm{N}$ and $50 \% \mathrm{~K}$ was applied as $90^{\text {th }}$ day after at earthing up. First drip irrigation was given immediately after planting. Subsequent drip irrigations were scheduled for 2 hours day ${ }^{-1}$. The discharge rate of emitter used for the experiment was $5 \mathrm{~L} \mathrm{hr}^{-}$ 
Growth parameters and dry matter production were observed at all growth stages. Based on nutrient content of stalk, dry leaves and green tops nutrient uptake of sugarcane was calculated at harvest stage. Plant $\mathrm{N}$ content was estimated by micro kjeldahl digestion and distillation method (Jackson, 1973). Plant P and $\mathrm{K}$ content was estimated by tri-acid extract with $\mathrm{HNO}_{3}, \mathrm{H}_{2} \mathrm{SO}_{4}$ and $\mathrm{HClO}_{4}$ in 9:2:1 ratio (Piper, 1966).

The data attributed to yield of the crop were recorded or calculated at all growth stages of the crop viz., Survived hill population, single cane weight, cane weight of individual hill, no. of canes per hill, no of millable cane.

The nutrient uptake of above ground parts of sugarcane was calculated using the following formula.

\begin{tabular}{lc} 
Nutrient & $\begin{array}{c}\text { Nutrient content }(\%) \times \text { Total dry } \\
\text { matter yield }\left(\mathrm{kg} \mathrm{ha}^{-1}\right)\end{array}$ \\
\cline { 2 - 2 } & 100
\end{tabular}

For this tiller count was recorded at 120 DAP and number of millable cane were calculated at harvest and calculated by the above formula.

\section{Results and Discussion}

A high survived hill population of 7834.20 (70 $\%$ ) was observed in $\mathrm{T}_{7}$ which received sugar industry biocompost at $2 \mathrm{t} \mathrm{ha}^{-1}$, it is also noted that it was on par with other treatments. Similar findings were observed in the works of Zeleke et al., (2014). Which tells that the amount of nutrients supplied or other additional inputs does not have any significant contributions towards population. The highest recorded single cane weight $(2.12 \mathrm{~kg})$ was observed to be in $T_{7}$ which received sugar industry biocompost at $2 \mathrm{t} \mathrm{ha}^{-1}$, the lowest recorded weight of $1.41 \mathrm{~kg}$ was observed in $\mathrm{T}_{1}$ which received $50 \%$ of NPK via NPP (Table 1). Similar findings were obtained by Hemalatha (2015) where a highest recorded cane weight $(1.63 \mathrm{~kg})$ was noted in the treatment which received nitrogen at $195.5 \mathrm{~kg}$ $\mathrm{ha}^{-1}$ followed by $(1.43 \mathrm{~kg})$ nitrogen at $161 \mathrm{~kg}$ $\mathrm{ha}^{-1}$.

The highest no. of millable cane (96752.37) was noted in the $\mathrm{T}_{7}$, followed by $\mathrm{T}_{4}$ which received $125 \%$ NPK via NPP (90831.28). Similar work was carried out by Namitha et al., (2008) where they got 132407 millable canes in the treatments which received $50 \%$ on $\mathrm{N}$ from sugar mill biocompost and $50 \%$ from fertilizers.

The yield obtained varied from treatment to treatments. The highest yield of $123 \mathrm{t} \mathrm{ha}^{-1}$ was observed in $\mathrm{T}_{7}$, followed by $\mathrm{T}_{4}\left(116.8 \mathrm{tha}^{-1}\right)$ it was found to be on par with $T_{3}, T_{5}$ and $T_{6}$. Similar result was observed by Rakkiyappan et al., (2001), where $100 \%$ NPK gave $84.3 \mathrm{t}$ $\mathrm{ha}^{-1}$ and $75 \% \mathrm{NPK}+10 \mathrm{t}$ biocompost gave $86.0 \mathrm{t} \mathrm{ha}^{-1}$. They justified their results by saying that application of organics improved the soil organic carbon and available NPK status. The work of Rama et al., (2011) who has recorded $93.88 \mathrm{t} \mathrm{ha}^{-1}$, the highest yield recorded in the treatment which received $2.5 \mathrm{t}$ $\mathrm{ha}^{-1}$ of compost along with $100 \%$ recommended NPK. Such results are due to the balanced use of chemical fertilizers alone will not be able to sustain the cane productivity due to gradual emergence of deficiency of one or more secondary and micronutrients. Integrated use of chemical fertilizers and organic manures resulted in markedly higher productivity besides bringing out a general improvement in soil fertility status than that of chemical fertilizers alone. The recordings in general show that the application of sugar industry biocompost to the cane prior to ploughing at $2 \mathrm{t} \mathrm{h}^{-1}$ enhances the vital yield parameters of sugarcane.

\section{Dry matter production}

Dry matter production of sugarcane was recorded stage wise (not presented) and 
presented separately as cane stalk, dry leaves and green tops at harvest stage (Table 2). More dry matter was produced by the cane stalk followed by green tops finally the dry leaves. Highest dry matter of cane stalk was observed in $\mathrm{T}_{7}\left(39374 \mathrm{~kg} \mathrm{ha}^{-1}\right)$, followed by $\mathrm{T}_{5}$ $\left(37178 \mathrm{~kg} \mathrm{ha}^{-1}\right)$. The dry matter produced by the dry leaves was found to be high in $\mathrm{T}_{7}$ $\left(4650 \mathrm{~kg} \mathrm{ha}^{-1}\right)$, followed by $\mathrm{T}_{5}\left(4437 \mathrm{~kg} \mathrm{ha}^{-1}\right)$. Similar pattern of dry matter production was also expressed in green tops at harvest stage, where $\mathrm{T}_{7}$ recorded high (6240 kg ha-1), followed by $\mathrm{T}_{5}\left(6164 \mathrm{~kg} \mathrm{ha}^{-1}\right)$. Similar results were obtained by Henrique et al., (2010). The values of dry matter from cane stalk, dry leaves and green tops coincide with the yield parameters (Table 1). The ratio of dry matter produced by the plant was observed in the order of cane stalk $>$ green tops $>$ dry leaves.

\section{Nutrient uptake by the crop}

The uptake of $\mathrm{N}, \mathrm{P}$ and $\mathrm{K}$ by the sugarcane was recorded from cane stalk, dry leaves and green tops separately (not presented) and the total uptake is calculated as a whole representing every single treatment (Table 3 ). The highest amount of $\mathrm{N}$ uptake was found to be in the $\mathrm{T}_{7}\left(254.26 \mathrm{~kg} \mathrm{ha}^{-1}\right)$ followed by $\mathrm{T}_{5}$ $\left(249.40 \mathrm{~kg} \mathrm{ha}^{-1}\right)$. Similar results were obtained by Rama et al., (2011) where the uptake was found to be increased when compost was added@2.5 t ha ${ }^{-1}$, it is also to be noted that the other amendments like FYM @ $12.5 \mathrm{t} \mathrm{ha}^{-1}$ has not triggered the uptake of the crop.

The $\mathrm{P}$ uptake was found to be high in $\mathrm{T}_{7}$ (54.97 $\mathrm{kg} \mathrm{ha}^{-1}$ ) followed by $\mathrm{T}_{5}\left(53.23 \mathrm{~kg} \mathrm{ha}^{-1}\right)$. In 2001 Rakkiyappan et al., (2001) has found out the uptake of $\mathrm{P}$ as check and found out the uptake was (46.31 $\left.\mathrm{kgha}^{-1}\right)$ for $100 \%$ NPK. A similar pattern of increased uptake of the compost applied treatment over the RDF was of uptake was also observed in the experiment of Rama et al., (2011). Being a sugar crop, the uptake of potassium is noted to be equal to the uptake of nitrogen in all the treatments. More uptake of potassium was noted in $\mathrm{T}_{7}$ (251.41 $\left.\mathrm{kg} \mathrm{ha}^{-1}\right)$ followed by $\mathrm{T}_{4}\left(235.38 \mathrm{~kg} \mathrm{ha}^{-1}\right)$ where $125 \%$ of potassium has been given.

Table.1 Yield parameters observed

\begin{tabular}{|c|c|c|c|c|c|c|}
\hline & Treatments & $\begin{array}{l}\text { Survived hill } \\
\text { population } \\
\left(\text { no. ha }^{-1}\right)\end{array}$ & $\begin{array}{l}\text { Single cane } \\
\text { weight }(\mathrm{kg})\end{array}$ & $\begin{array}{l}\text { No. of } \\
\text { canes } \\
\left(\text { hill }^{-1}\right)\end{array}$ & $\begin{array}{c}\text { No. of } \\
\text { millable } \\
\text { cane }\left(h^{-1}\right)\end{array}$ & $\begin{array}{l}\text { Yield } \\
\left(\mathrm{t} \mathrm{ha} \mathbf{~}^{-1}\right)\end{array}$ \\
\hline $\mathbf{T}_{1}$ & NPP: $50 \%$ NPK & 7608.39 & 1.41 & 9.19 & 69921.10 & 71.3 \\
\hline $\mathbf{T}_{2}$ & NPP: $75 \%$ NPK & 7703.79 & 1.66 & 10.10 & 77808.28 & 92.6 \\
\hline $\mathbf{T}_{3}$ & NPP: $100 \%$ NPK & 7776.01 & 1.88 & 11.24 & 87402.35 & 112.3 \\
\hline $\mathbf{T}_{4}$ & NPP: $125 \%$ NPK & 7789.99 & 1.88 & 11.66 & 90831.28 & 116.8 \\
\hline $\mathbf{T}_{5}$ & $\begin{array}{l}\text { NPP: } 100 \% \text { NPK + } \\
\text { MN }\end{array}$ & 7792.16 & 1.87 & 11.55 & 89999.45 & 115.2 \\
\hline $\mathbf{T}_{6}$ & $\begin{array}{l}\text { NPP: } 100 \% \text { NPK + } \\
\text { Mulch }\end{array}$ & 7779.12 & 1.85 & 11.31 & 87981.85 & 113.6 \\
\hline $\mathbf{T}_{7}$ & $\begin{array}{l}\text { NPP: } 100 \% \text { NPK + } \\
\text { SIBC }\end{array}$ & 7834.20 & 2.12 & 12.35 & 96752.37 & 123.6 \\
\hline $\mathbf{T}_{8}$ & $\begin{array}{l}\text { SA : } 100 \% \text { NPK + } \\
\text { FYM }\end{array}$ & 7726.72 & 1.71 & 10.52 & 81285.09 & 97.8 \\
\hline \multirow[t]{3}{*}{$\mathbf{T}_{9}$} & Control & 7454.70 & 1.44 & 7.51 & 55984.8 & 31.7 \\
\hline & SEd & 369.54 & 0.10 & 0.58 & 9675.237 & 5.83 \\
\hline & $\mathrm{CD}(\mathrm{P}=0.05)$ & 783.42 & 0.21 & 1.24 & 4563.791 & 12.36 \\
\hline
\end{tabular}


Table.2 DMP at sugarcane stalk, leaves and green tops at harvest stage ( $\left.\mathrm{kg} \mathrm{ha}^{-1}\right)$

\begin{tabular}{|c|c|c|c|c|}
\hline & Treatments & Cane stalk & Dry leaves & Green tops \\
\hline $\mathbf{T}_{1}$ & NPP: $50 \%$ NPK & 24748 & 3803 & 4722 \\
\hline $\mathbf{T}_{2}$ & NPP: $75 \%$ NPK & 31064 & 4302 & 5432 \\
\hline $\mathbf{T}_{3}$ & NPP: $100 \%$ NPK & 35805 & 4774 & 5893 \\
\hline $\mathbf{T}_{4}$ & NPP: $125 \%$ NPK & 36957 & 4930 & 6066 \\
\hline $\mathbf{T}_{5}$ & NPP: $100 \% \mathrm{NPK}+\mathrm{MN}$ & 37178 & 5008 & 6164 \\
\hline $\mathbf{T}_{6}$ & NPP: $100 \%$ NPK + Mulch & 36648 & 4959 & 6061 \\
\hline $\mathbf{T}_{7}$ & NPP: $100 \%$ NPK + SIBC & 39374 & 5115 & 6240 \\
\hline $\mathbf{T}_{8}$ & $\mathrm{SA}: 100 \% \mathrm{NPK}+\mathrm{FYM}$ & 31951 & 4540 & 5531 \\
\hline $\mathbf{T}_{9}$ & Control & 14522 & 2818 & 3438 \\
\hline & SEd & 1857.26 & 241.27 & 294.34 \\
\hline & $\mathrm{CD}(\mathbf{P}=\mathbf{0 . 0 5})$ & 3937.40 & 511.50 & 624.00 \\
\hline
\end{tabular}

Table.3 Uptake at after harvest in above ground parts $\left(\mathrm{kg} \mathrm{ha}^{-1}\right)$

\begin{tabular}{|c|c|c|c|c|}
\hline & Establishment & Nitrogen & Phosphorus & Potassium \\
\hline $\mathbf{T}_{1}$ & NPP: $50 \%$ NPK & 164.64 & 30.42 & 153.00 \\
\hline $\mathbf{T}_{2}$ & NPP: $75 \%$ NPK & 193.89 & 40.56 & 193.25 \\
\hline $\mathbf{T}_{3}$ & NPP: $100 \%$ NPK & 230.78 & 48.49 & 230.88 \\
\hline $\mathbf{T}_{4}$ & NPP: $125 \%$ NPK & 246.03 & 52.36 & 235.38 \\
\hline $\mathbf{T}_{5}$ & NPP: $100 \%$ NPK + MN & 249.40 & 53.23 & 231.20 \\
\hline $\mathbf{T}_{6}$ & NPP: $100 \%$ NPK + Mulch & 234.36 & 50.42 & 231.71 \\
\hline $\mathbf{T}_{7}$ & NPP: $100 \%$ NPK + SIBC & 254.26 & 54.97 & 251.41 \\
\hline $\mathbf{T}_{8}$ & SA : $100 \%$ NPK + FYM & 199.45 & 42.30 & 199.61 \\
\hline \multirow[t]{3}{*}{$\mathbf{T}_{9}$} & Control & 58.59 & 16.89 & 76.76 \\
\hline & SEd & 11.99 & 2.59 & 11.86 \\
\hline & $\mathrm{CD}(\mathrm{P}=0.05)$ & 25.43 & 5.50 & 25.14 \\
\hline
\end{tabular}

Table.4 Sugar quality parameters of sugarcane under Surface irrigation at harvest

\begin{tabular}{|c|c|c|c|c|c|}
\hline & Treatments & Brix (\%) & Pol (\%) & Purity (\%) & Sugar recovery $(\%)$ \\
\hline $\mathbf{T}_{1}$ & NPP: $50 \%$ NPK & 20.08 & 18.28 & 50.15 & 12.37 \\
\hline $\mathbf{T}_{2}$ & NPP: $75 \%$ NPK & 21.39 & 18.86 & 68.97 & 13.04 \\
\hline $\mathbf{T}_{3}$ & NPP: $100 \%$ NPK & 22.55 & 19.44 & 81.73 & 13.77 \\
\hline $\mathbf{T}_{4}$ & NPP: $125 \%$ NPK & 22.86 & 19.69 & 89.17 & 13.98 \\
\hline $\mathbf{T}_{5}$ & NPP: $100 \% \mathrm{NPK}+\mathrm{MN}$ & 22.77 & 19.69 & 87.87 & 13.80 \\
\hline $\mathbf{T}_{6}$ & NPP: $100 \%$ NPK + Mulch & 22.58 & 19.50 & 81.52 & 13.82 \\
\hline $\mathbf{T}_{7}$ & NPP: $100 \%$ NPK + SIBC & 23.00 & 20.00 & 90.00 & 14.00 \\
\hline $\mathbf{T}_{8}$ & SA : $100 \%$ NPK + FYM & 21.48 & 19.13 & 71.67 & 13.16 \\
\hline $\mathbf{T}_{9}$ & Control & 18.00 & 17.00 & 18.00 & 11.00 \\
\hline & SEd & 1.08 & 0.94 & 4.25 & 0.66 \\
\hline & $\mathrm{CD}(\mathrm{P}=0.05)$ & 2.30 & 2.00 & 9.10 & 1.39 \\
\hline
\end{tabular}




\section{Sugar quality and recovery}

In this experiment average brix $\%$ values are recorded for each treatment (Table 4) and it was noted that the $\mathrm{T}_{7}(23.00 \%)$ recorded high value but found to be in on par with the other treatments. The pol or sucrose per cent was calculated in all the treatments and found that in $\mathrm{T}_{7}(20.00 \%)$ with the highest pole percentage and also on par with the other treatments. In $\mathrm{T}_{5}$ the Pol or sucrose $\%$ was 19.69 , this finding is in concordance with the findings of Naga et al., (2013) where RDF + $50 \mathrm{~kg} \mathrm{ZnSO}_{4}$ application gave $19.57 \%$.

The purity per cent of the treatments were analyzed and the highest value was found to be in T7 (14.00\%) and also on par with the other treatments. Similar to the brix value the sugar recovery was also found to be without much difference, the highest recovery is noted in $\mathrm{T} 7$.

The increasing trend of the values of the quality parameters follows the trend obtained in the works of Andressa et al., (2016). The biocompost received treatment has the highest values in all the parameters of sugar quality, this finding is in concordance with the findings of Bokhtiar and Katsutoshi (2005).

On observation Subsurface application of urea and other fertilizers via NPP seems to be the most practical way to reduce $\mathrm{N}$ loss by ammonia volatilization or other nutrient losses such as leaching and runoff. When the fertilizer was paced below the soil surface there was sufficient moisture in the soil for hydrolysis to commence immediately after fertilizer application. The application of SIBC prior to ploughing under drip irrigation has effectively influenced in proper decomposition which ultimately made the soil to hold and made the applied nutrients to the crop in an effective manner.

\section{References}

Andressa F. L. Rhein, Renata P. Pincelli, Marcel T. Arantes, William J. Dellabiglia, Oriel T. Kölln and Marcelo de A. Silva. 2016. Technological quality and yield of sugarcane grown under nitrogen doses via subsurface drip fertigation. Revista Brasileira de Engenharia Agrícola e Ambiental. 20(3): 209-214.

Bokhtiar, S.M. and Katsutoshi Sakurai. 2005. Effect of Application of Inorganic and Organic Fertilizers on growth, yield and quality of sugarcane. Sugar Tech. 7(I):33-37.

Dale, D.W., Prado, R.M., Cantarella, H., Fonseca, I.M., Avalhães, C.C., Correia, M.A.R., Barbosa, M.P. 2013. Ammonium and nitrate in soil and ratoon sugarcane grown in function of nitrogen on Oxisol. Journal of Plant Nutrition. 36:201-213.

Dalri, A.B., Cruz, R.L., Garcia, C.J.B., Duenhas, L.H. 2008. Irrigação por gotejamento subsuperfical na produção e qualidade de cana-deaçúcar. Irriga. 13:1-11.

Dantas Neto. J., Figueredo. J.L.C., Farias. C.H.A., Azevedo.H.M.de., Azevedo, C.A.V.de. Resposta da cana-deaçúcar, primeira soca, a níveis de irrigação e adubação de cobertura. 2006. Revista Brasileira de Engenharia Agrícola e Ambiental. 10:283-288.

Drip Irrigation Technology to save Water and Enhance Crop Yields. 2017. Research bulleti, ICAR.

Hemalatha.S. 2015. Impact of Nitrogen Fertilization on Quality of Sugarcane under Fertigation. International Journal of Research and Scientific Innovation. 2(3).

Henrique Coutinho Junqueira Franco; Paulo Cesar Ocheuze Trivelin; Carlos 
Eduardo. Faroni; André Cesar Vitti; Rafael Otto. 2010. Stalk yield and technological attributes of planted cane as related to nitrogen fertilization. Scientific Agriculture. 67(5):579-590.

Muchow, R.C., Robertson, M.J., Wood, A.W., Keating, B.A. 1996. Effect of nitrogen on the time-course of sucrose accumulation in sugarcane. Field Crops Research. 47:143-153.

Naga Madhuri, K.V., Sarala, N.V., Hemanth Kumar, M., Subba Rao, M. and Giridhar, V. 2013. Influence of Micronutrients on Yield and Quality of Sugarcane. Sugar Tech. 15(2):187191.

Namita Chauhan, Singh. M.P., Aneg Singh, Singh. A.K., Chauhan. S.S. and Singh, S.B. 2006. Effect of biocompost application on sugarcane crop. Sugar tech. 10(2):174-176.

Pandian, T.P, Raghavendra, B.T., Karthik Pandi, V., Guru Pirasanna Pandi, G., and Soumia, P.S. 2014. Sustainable Sugarcane Initiative (SSI). Popular Kheti. 2 (2):16-19.

Premalatha, R.P., Bhakiyathu Saliha, B. 2016. Impact of Fertilizer Sources and Levels on the Available Soil Nutrients and Yield of Sugarcane. International Journal of Engineering Science and
Computing, 6(9):2347-2351.

Rakkiyappan, P, Thangavelu, S., Malathi, R., and Radhamani, R. 2001. Effect of biocompost and enriched pressmud sugarcane yield and quality. Sugar tech. 3(3):92-96.

Rama Lakshmi, Ch.S., Sreelatha, T., Usha Rani, T., Rao, S.R.K. and Naidu, N.V. 2011. Effect of organic manures on soil fertility and productivity of sugarcane in North coastal zone of Andhra Pradesh. Indian Journal of Agricultural Research. 45(4):307-313.

Silva, M.A., Arantes, M.T., Rhein, A.F L., Gava, G.J.C. and Kolln, O.T. 2014. Potencial produtivo da cana-de-açúcar sob irrigação por gotejamento em função de variedades e ciclos. Revista Brasileira de Engenharia Agrícola e Ambiental. 18:241-249.

Singh, V.K., Shukla, A.K., Gilt, M.S, Sharma, S.K. and Tiwari, K.N. 2008. Improving sugarcane productivity through Balanced nutrient with potassium, sulphur and magnesium. Better crops Int., 12-14.

Zeleke Teshome, Girma Abejehu and Hadush Hagos. 2014. Effect of Nitrogen and Compost on Sugarcane (Saccharum officinarum L.) at Metahara Sugarcane Plantation. Advances in Crop Science and Technology. 2(5):1-4.

\section{How to cite this article:}

Raja Rajeshwaran, TH.SA. and Arulmozhiselvan, K. 2018. Performance of Nutri Pellet Pack Technology in Sugarcane Yield and Uptake under Drip Irrigation. Int.J.Curr.Microbiol.App.Sci. 7(07): 1418-1425. doi: https://doi.org/10.20546/ijcmas.2018.707.169 